\title{
KAJIAN YURIDIS PERALIHAN HAK CIPTA SEBAGAI OBJEK WAKAF
}

\author{
Heniyatun \\ Fakultas Hukum Universitas Muhammadiyah Magelang \\ Email: heni.suprapto@yahoo.co.id; \\ Puji Sulistyaningsih \\ Fakultas Hukum Universitas Muhammadiyah Magelang \\ Email: pujisulistyaningsih@yahoo.com: \\ Heni Hendrawati \\ Fakultas Hukum Universitas Muhammadiyah Magelang \\ Email: henihendrawati22@yahoo.com
}

\begin{abstract}
Abstrak
Penelitian ini mengkaji tentang objek wakaf berupa Kekayaan Intelektual (KI). Hal ini ini sebagaimana diatur dalam UU Nomor 41 Tahun 2004, Pasal 16 ayat (3), bahwa Hak Cipta merupakan salah satu lingkup KI, yang dapat menjadi objek wakaf. Demikian dalam UU Nomor 28 Tahun 2014, bahwa salah satu peralihan Hak Cipta adalah dengan diwakafkan. Perlu dipahami ketika akan mewakafkan hak cipta apakah yang akan diwakafkan hak ekonominya atau hak moralnya saja, atau keduanya, karena hak moral melekat pada diri pencipta, apakah dapat dialihkan. Tujuan dalam penelitian ini adalah untuk mengetahui prosedur peralihan hak cipta sebagai objek wakaf. Jika hak cipta dialihkan melalui wakaf bagaimana akibat hukumnya, karena terkait dengan hak moral yang melekat pada pencipta. Selain itu juga untuk mengetahui bagaimana keabsahan wakaf hak cipta tersebut. Metode yang digunakan dalam penelitian ini adalah deskriptif analitis dan diolah secara kualitatif. Pendekatan yang digunakan melalui pendekatan yuridis normatif. Hasil penelitian menunjukan bahwa prosedur peralihan hak cipta sebagai objek wakaf secara teknis sama dengan objek wakaf yang lain, yang membedakan hanya ikrar wakafnya saja, selain itu juga disyaratkan adanya surat pendaftaran(maksudnya adalah pencatatan) ciptaan dari Dirjen KI Kementerian Hukum dan HAM. Akibat hukumnya adalah ketika wakif sudah mewakafkan maka haknya sudah beralih pada penerima wakaf. Namun hak yang dapat beralih hanya hak ekonominya saja, sedangkan hak moral tetap melekat pada diri pencipta (wakif), perlindungan hukum untuk hak cipta sesuai yang diberikan oleh Undang-Undang Hak Cipta (sesuai dengan hasil ciptaannya), sehingga wakaf hak cipta ini sifatnya sementara. Mengenai keabsahan batasan waktu wakaf dengan objek hak cipta, para ulama (responden) membolehkan wakaf dengan batasan waktu. Hal ini sesuai dengan kemanfaatan dari wakaf tersebut.
\end{abstract}

Kata Kunci: Hak Cipta; Peralihan Hak Cipta; Objek Wakaf

\begin{abstract}
This research reviewing waqf object as an Intelectual Property which is in accordance with the Indonesian constitution Number 41 year of 2004, article 16 paragraph (3). Copyright is one of intellectual property that may become object of waqf. It is
\end{abstract}


mentioned in the Constitution number 28 year of 2014 that one form of copyright is by doing waqf. However, when someone does the waqf of his copyright, it should be noticed whether the donation of copyright is only the economic right or the moral right or even both. Since the moral right is involved on creator, could it be transferred? The goal of this research is to know the procedure of copyright transfer as waqfobject. If the copyright is transferred by waqf, how is the legal consequence related to the moral right that involved in. Another goal is to know the validity of the copyright waqf as there is time limitation of ownership in copyright. To realize the goal, the research used juridical normative method. The result shown that the procedure of copyright transfer as waqf object is similar with other waqf objects, except for the waqf pledge and the requirement of registration letter of creation from the Director General of Intellectual Property of Ministry of Law and Human Right. The legal consequence of it is that when waqif (person doing the waqf) does waqf, his right is transferred to the recipient of waqf. However, it is only economic right that can be transferred, whereas the moral right is still attached to the creator (waqif). The legal protection for copyright is based on the Constitution of copyright (in accordance with his creation), so the copyright waqf has temporary time only. Dealing with the validity of limited time waqf of copyright, most Islamic Priests (respondents) allow it. It's appropriate to the benefit of the waqf.

\section{Keywords: Copyright; Copyright Transfer; The Object of Waqf}

\section{A. LATAR BELAKANG}

Kemajuan ilmu pengetahuan dan teknologi berpengaruh terhadap Fikih Muamalah, khusususnya yang menyangkut objek wakaf. Ketentuan di dalam fikih menjelaskan bahwa benda yang diwakafkan haruslah benda yang tidak bergerak. Namun dengan kemajukan ilmu pengetahuan dan teknologi terdapat perluasan objek wakaf, yaitu tidak hanya berupa benda tetap, tetapi dapat juga berupa benda bergerak, bahkan benda bergerak yang tidak berwujud, misalnya Kekayaan Intelektual (KI). Hal ini sesuai dengan Undang-Undang Nomor 41 Tahun 2004 tentang Wakaf, Pasal 16 ayat (3). Ketentuan tersebut diperjelas lagi dalam Peraturan Pemerintah Nomor 42 Tahun 2006, yang merupakan peraturan pelaksana UndangUndang Nomor 41 Tahun 2004, bahwa objek wakaf dapat berupa benda bergerak yang berupa uang dan benda bergerak yang tidak berupa uang. Hak Cipta merupakan salah satu lingkup KI yang dapat menjadi objek wakaf berupa benda bergerak. Hal tersebut dengan Undang-Undang Nomor 28 Tahun 2014 tentang Hak Cipta, disebutkan bahwa salah satu peralihan Hak Cipta adalah dengan diwakafkan.

Diundangkannya Undang-Undang Nomor 41 Tahun 2004 perlu disambut dengan baik bagi umat Islam yang akan melaksakan ibadah Ijtimā'iyyah (ibadah sosial) untuk mencari rida Allah SWT, yaitu bagi yang akan melakukan perwakafan tetapi tidak mempunyai tanah. Hal ini telah terpecahkan dengan lahirnya undangundang tentang wakaf tersebut sebagai penyempurnaan Peraturan Pemerintah Nomor 28 Tahun 1977 Tentang Perwakafan Tanah Milik, sebab selain untuk menjamin kepastian hukum, undang-undang tersebut juga merupakan unifikasi hukum perwakafan di Indonesia, yaitu bahwa kekayaan yang dapat diwakafkan 
tidak hanya yang terbatas kekayaan materiil saja, akan tetapi kekayaan immateriilpun dapat diwakafkan.

Berdasarkan Pasal 16 ayat (3) huruf e Undang-Undang Nomor 41 Tahun 2004, bahwa kekayaan intelektual (KI) yang dapat diwakafkan termasuk dalam kategori benda bergerak yang tidak berwujud. Kekayaan Intelektual tersebut meliputi Hak Cipta (copyright) dan Kekayaan Industri (industrial property right). Kekayaan Industri (industrial property right) terdiri dari Paten, Merek, Varietas Tanaman, Rahasia Dagang, Desain Industri, dan Desain Tata Letak Sirkuit Terpadu. Hak Cipta merupakan salah satu kekayaan intelektual berupa suatu karya di bidang ilmu pengetahuan, seni dan sastra merupakan salah satu objek wakaf.

Permasalahan mulai timbul ketika mewakafkan hak cipta, karena di dalam hak cipta batasan waktu kepemilikan hak berbeda-beda sesuai dengan jenis hasil karya yang diciptakan. Masa berlaku hak ekonomi ada yang selama hidup pencipta dan terus berlangsung selama 70 (tujuh puluh) tahun setelah pencipta meninggal dunia. Namun ada juga yang masa perlindungannya hanya berlaku 50 (lima puluh) tahun atau bahkan ada yang hanya selama 25 (dua puluh lima) tahun sejak pertama kali diumumkan. Perlu dipahami pula bahwa di dalam Hak Cipta terdapat hak moral dan hak ekonomi, ketika akan mewakafkan hak cipta apakah yang akan diwakafkan hak ekonominya atau hak moralnya saja, atau keduanya, karena hak moral melekat pada diri pencipta, apakah juga dapat dialihkan? Kemudian hak apa saja yang melekat pada penerima wakaf setelah wakif mewakafkan hak ciptanya tersebut? Pertanyaan selanjutnya adalah, dapatkah hak cipta yang termasuk benda tak berwujud yang belum dikenal di era para mujtahidīn dan bahkan dalam fikih iftirādī (prediktif), termasuk harta yang dapat diwakafkan?

Berdasarkan latar belakang tersebut, maka permasalahan yang akan diselesaikan dalam penelitaian ini meliputi:

1. Bagaimana prosedur peralihan hak cipta yang dijadikan sebagai objek wakaf?

2. Bagaimana akibat hukumnya terhadap si pencipta jika hak cipta diwakafkan?

3. Bagaimana keabsahan wakaf hak cipta yang dibatasai waktu kepemilikan haknya?

\section{B. METODE PENELITIAN}

Metode pendekatan yang digunakan dalam penelitian ini adalah, metode pendekatan yuridis normatif, yaitu suatu penelitian yang menekankan pada ilmu hukum atau berpedoman pada segi yuridis, yaitu berusaha menelaah peraturanperaturan hukum yang berlaku (Soerjono, 2005: 264). Jenis penelitian ini adalah penelitian deskriptif, yaitu suatu penelitian yang dilakukan dengan cara mendeskripsikan secara sitematis, faktual, dan akurat terhadap suatu obyek yang ditetapkan untuk menemukan sifat-sifat, karakteristik, serta faktor-faktor tertentu yang dimulai dari peraturan dan teori umum yang dipublikasikan terhadap data yang diperoleh untuk menjawab permasalahan (Soerjono, 2005: 36).

Metode pengumpulan data dalam penelitian ini meliputi data primer dan data sekunder. Data primer dalam penelitian ini diperoleh dari lapangan, yaitu dilakukan 
wawancara dengan responden, sedangkan data sekunder diperoleh dari studi kepustakaan.

Penelitian ini juga menggunakan metode survey sampel, yaitu informasi yang dikumpulkan dari sebagian populasi untuk mewakili seluruh populasi. Penentuan responden didasarkan pada metode non-random sampling atau purposive sampling, yaitu penarikan sampel dilakukan dengan cara mengambil sampel yang didasarkan pada tujuan tertentu serta dicari anggota sampel yang benar-benar mencerminkan populasinya artinya tidak semua unsur dalam populasi mempunyai kesempatan yang sama untuk menjadi sampel. Adapun pemilihan sampel didasarkan pada ciriciri khusus yang mempunyai hubungan dengan permasalahan penelitian.

Penelitian dilakukan dengan studi pustaka, dan wawancara/ interview dengan responden. Metode analisis data menggunakan metode deskriptif analitis, dan diolah dengan metode kualitatif.

\section{PEMBAHASAN}

1. Tinjauan Umum

\section{a. Hak Kekayaan Intelektual (HKI)}

Istilah hak kekayaan intelektual (HKI) merupakan terjemahan dari Intelectual Property Rights (IPR), yang dideskripsikan sebagai kekayaan yang timbul atau lahir karena kemampuan inteletual manusia. Konsepsi mengenai HKI didasarkan pada pemikiran bahwa karya intelektual yang telah dihasilkan manusia memerlukan pengorbanan tenaga, waktu, dan biaya. Pengorbanan tersebut menjadikan karya yang telah dihasilkan memiliki nilai ekonomi karena manfaatnya dapat dinikmati. Hal tersebut mendorong adanya penghargaan atas hasil karya yang telah dihasilkan berupa perlindungan hukum bagi HKI. Tujuan pemberian perlindungan hukum ini untuk mendorong dan menumbuh kembangkan semangat berkarya dan mencipta. Adapun objek yang diatur di dalam HKI adalah karya-karya yang timbul atau lahir karena kemampuan intelektual manusia.

Menurut Dicky R Munaf, HKI merupakan hak yang berasal dari karya, karsa, cipta manusia, karena lahir dari kemampuan intelektualitas manusia dan merupakan hasil kegiatan kreatif suatu kemampuan daya pikir manusia yang diekspresikan kepada khalayak umum dalam berbagai bentuknya, yang memiliki manfaat serta berguna dalam menunjang kehidupan manusia juga mempunyai nilai ekonomi. Esensi yang terpenting dari setiap bagian HKI adalah adanya suatu ciptaan tertentu. Bentuk nyata dari ciptaan tersebut bisa di bidang teknologi, ilmu pengetahuan, seni dan sastra (dalam Riswandi, 2016: 29).

Menurut Djumhana (1995: 107) HKI merupakan suatu hak milik yang berada dalam ruang lingkup kehidupan ilmu pengetahuan, teknologi, maupun seni dan sastra. Pemiliknya bukan terhadap barangnya melainkan terhadap hasil kemampuan intelektual manusianya, yaitu diantaranya berupa ide. Hak kekayaan intelektual ini baru ada bila kemampuan intelektual manusia itu telah membentuk sesuatu yang bisa dilihat, didengar, dibaca, maupun digunakan secara praktis. 
Hak Kekayaan Intelektual (HKI) merupakan hak eksklusif yang diberikan oleh suatu peraturan kepada seseorang atau sekelompok orang atas karya ciptanya. Kata "intelektual" tercermin bahwa obyek kekayaan intelektuan tersebut adalah kecerdasan, daya pikir, atau produk pemikiran manusia (the Creation of the Human Mind). Hak eklusif yang diberikan negara kepada individu pelaku HKI (inventor, pencipta, pendesain dan sebagainya) tiada lain dimaksudkan sebagai penghargaan atas hasil karya (kreativitas), agar orang lain terangsang untuk dapat lebih lanjut mengembangkannya lagi, sehingga dengan sistem HKI tersebut kepentingan masyarakat ditentukan melalui mekanisme pasar. Kekayaan intelektual merupakan kekayaan atas segala hasil produksi kecerdasan daya pikir seperti teknologi, ilmu pengetahuan, seni, sastra, gubahan lagu, karya tulis, karikatur, dan lain-lain yang berguna untuk manusia. Sehingga dapat ditarik kesimpulan bahwa HKI adalah hak yang berasal dari hasil kegiatan kreatif suatu kemampuan daya berpikir manusia yang mengepresikan kepada khalayak umum dalam berbagai bentuk, yang memiliki manfaat serta berguna dalam menunjang kehidupan manusia, juga mempunyai nilai ekonomis yang melindungi karya-karya intelektual manusia tersebut.

Perlindungan HKI diberikan oleh negara atas ide atau hasil karya warga negaranya. Perlindungan HKI selain untuk melindungi kepentingan dari pihak pemilik yang mempunyai hak eksklusif terhadap hak ciptanya, juga untuk menghindarkan dari penggunaan pihak-pihak yang tidak berwenang (Lita, 2016: 160)

Klasifikasi Hak Kekayaan Intelektual berdasarkan TRIPs Agreement, meliputi: a. Hak Cipta dan hak-hak yang berkaitan dengan hak cipta (Copy Right and Related Right); b. Merek Dagang (Trademarks); c. Indikasi Geografis (Geographical Indication); d. Desain Industri (Industrial Desaign); e. Patents; f. Layout-Design (Topographies) of Integrated Circuits; g. Protection of Undisclosed Information; h. Control of anti competitive practices in contractual licences (Sutedi, 2009: 56). Adapaun klasifikasi HKI di Indonesia meliputi: a. Hak Cipta dan hak terkait; b. Paten; c. Merek; d. Desain Industri; e. Desain Tata Letak Sirkuit Terpadu; f. Rahasia Dagang; dan g. Perlindungan Vaietas Tanaman.

\section{b. Hak Cipta}

Berdasarkan Pasal 1 angka 1 Undang-Undang Nomor 28 Tahun 2014 (UUHC 2014), hak cipta adalah hak eksklusif pencipta yang timbul secara otomatis berdasarkan prinsip deklaratif setelah suatu ciptaan diwujudkan dalam bentuk nyata tanpa mengurangi pembatasan sesuai dengan ketentuan peraturan perundang-undangan.

Selain penafsiran otentik, pengertian hak cipta juga diberikan oleh doktrin, antara lain menurut Anwar Ibrahim (dalam Margono, 2003: 28), bahwa Hak Cipta merupakan semua hasil ciptaan manusia dalam bidang seni, sastra, dan ilmu pengetahuan, maka hak milik tersebut sudah sewajarnya apabila negara menjamin sepenuhnya perlindungan segala macam ciptaan yang merupakan karya intelektual manusia sebagai produk olah pikir. 
Menurut Patricia Loughlan (dalam Purba, 2009: 25), Hak Cipta merupakan bentuk kepemilikan yang memberikan pemegangnya hak eksklusif untuk mengawasi penggunaan dan memanfaatkan suatu kreasi intelektual, sebagaimana kreasi yang ditetapkan dalam kategori hak cipta, yaitu kesusastraan, drama, musik dan pekerjaan seni, serta rekaman suara, film, radio dan siaran televisi, serta karya tulis yang diperbanyak melalui perbanyakan (penerbitan).

Pencipta adalah seseorang atau beberapa orang yang secara sendiri-sendiri atau bersama-sama menghasilkan suatu ciptaan yang bersifat khas dan pribadi (Pasal 1 angka 2 UUHC 2014). Adapun pemegang hak cipta adalah pencipta sebagai pemilik hak cipta, pihak yang menerima hak tersebut secara sah dari pencipta, atau pihak lain yang sah (Pasal 1 angka 4 UUHC 2014). Sementara pengertian ciptaan berdasarkan Pasal 1 angka 3 UUHC 2014 adalah setiap karya cipta di bidang ilmu pengetahuan, seni, dan satra yang dihasilkan atas inspirasi, kemampuan, pikiran, imajinasi, kecekatan, keterampilan, atau keahlian yang diekspresikan dalam bentuk nyata.

Hak cipta sebagai hak eksklusif terdapat dua hak, yaitu hak moral dan hak ekonomi. Hak moral adalah hak yang melekat pada diri pencipta atau pelaku (seni, rekaman, siaran) yang tidak dapat dihilangkan dengan alasan apapun, walaupun hak cipta atau hak terkait telah dialihkan. Pelaksanaan hak moral ini misalnya pencantuman nama pencipta pada ciptaannya, walaupun hak cipta tersebut sudah dijual untuk dimanfaatkan pihak lain nama pencipta tetap harus dicantumkan. Jadi hak moral itu sifatnya abadi yang melekat pada diri pencipta, artinya tidak dapat dilihkan kepada pihak lain. Oleh karena itu kemanapun dan sampai derajat keberapapun Hak Cipta telah beralih atau dialihkan, Pemegang Hak Cipta tetap terkait untuk mengakui dan menghormati Hak Moral pencipta. Hak seperti itu di antaranya berupa kewajiban untuk selalu mencantumkan nama pencipta dalam ciptaan (Soelistyo, 2011: 97)

Menurut Abdulkadir Muhammad (2001: 21), hak moral adalah hak yang melindungi kepentingan reputasi pribadi atau penemu dan tidak dapat dipindahkan dari pencipta karena bersifat pribadi atau kekal. Selanjutnya dikatakan bahwa pada dasarnya hak moral mempunyai makna yang merujuk pada hak-hak yang bersifat pribadi dan memiliki dimensi non ekonomi.

Hak Ekonomi menurut Suyud Margono (2010: 25) adalah hak eksklusif pencipta atau pemegang hak cipta untuk mendapatkan manfaat ekonomi atas ciptaan. Hak ekonomi ini berupa hak untuk mengumumkan (publishing right) suatu ciptaannya dan hak untuk memperbanyak (reproduction right) hasil ciptaannya.

Hak moral yang diatur dalam UUHC 2014 Pasal 4 merupakan hak yang melekat secara abadi pada diri pencipta untuk: 1) Tetap mencantumkan atau tidak mencantumkan namanya pada salinan sehubungan dengan pemakaian ciptaannya untuk umum; 2) Menggunakan nama aliasnya atau samarannya; 3) Mengubah ciptaannya sesuai dengan keputusan dalam msyarakat; 4) Mengubah judul dan anak judul ciptaan; dan 5) Mempertahankan haknya dalam hal terjadi distorsi ciptaan, 
mutilasi ciptaan, modifikasi ciptaan, atau hal yang bersifat merugikan kehormatan diri atau reputasinya.

Hak ekonomi adalah hak untuk mengambil manfaat dari hak cipta yang dilindungi. Hak ekonomi terdiri dari: (Riswandi, dan Sujitno, 2016: 93-94)

a. The reproduction right atau hak reproduksi merupakan hak yang paling fundamental dari seluruh hak ekonomi. Hak ini diakui baik dalam Konvensi Bern, Universal Copyright Convention, maupun hukum hak cipta di setiap negara. Hak ini pada hakekatnya adalah memberi izin untuk mereproduksi, mengkopi atau menggandakan jumlah ciptaan dengan berbagai cara, misalnya dengan cara mencetak (print), atau secara mekanik. Itu sebabnya hak mereproduksi ini sering dibagi lagi menjadi printing right dan mechanical right.

b. The adaptation right adalah hak memberi izin melakukan adaptasi, aransemen, atau perbuatan lain untuk mengubah bentuk sebuah karya, misalnya menterjemahkan satu karya dari satu bahasa ke bahasa lain, membuat aransemen musik dan lain lain. The adaptation right dengan jelas diakui oleh The Bern Convention danUniversal Copyright Convention. Soal terminologi ada juga penulis yang memaknai hak ini sebagai alteration right yang mencakup adaptation right dan translation right.

a. The distribution right adalah hak memberi izin untuk mendistribusikan (menyebarkan) hasil penggandaan suatu karya kepada publik. Termasuk kelompok hak ini antara lain: menjual, menyewakan dan bentuk-bentuk lain pengalihan hasil perbanyakan dari suatu karya. Kecuali berhubungan dengan karya cinematografi di dalam The Bern Convention, the distribution right ini tidak jelas diakui di dalam The Bern Convention dan Universal Copyright Convention.

b. The public performance right adalah hak memberi izin untuk menampilkan suatu karya kepada publik. Hak ini juga diakui, baik di dalam The Bern Convention danUniversal Copyright Convention. Oleh penulis dan juga kalangan collecting society seperti Yayasan Karya Cipta Indonesia (YKCI), istilah yang dipergunakan adalah performance right yang di dalamnya termasuk menampilkan karya kepada publik secara langsung (live) maupun melalui penyiaran (broadcast).

c. The broadcasting right, hak memberi izin untuk menyiarkan suatu karya dengan menggunakan kabel. Ada dua bentuk penyiaran dengan kabel, yaitu cable transmission dan cable origination. Bentuk yang pertama adalah pentransmisian kembali dengan kabel suatu penyiaran karya, jadi merupakan sebuah kegiatan meneruskan yang sudah ada (pre-existing). Bentuk yang kedua adalah pentransmisian asli dengan kabel karya. Di dalam the Bern Convention bentuk yang pertama ditempatkan sebagai bagian dari broadcasting right dan bentuk yang kedua diberlakukan sebagai salah satu bagian dari the public performance right. 
Hak cipta secara konsepsional merupakan hak hukum yang sifatnya eksklusif yang timbul secara deklaratif ketika ciptaan dapat diwujudkan secara nyata untuk jangka waktu tertentu. Namun demikian hak cipta secara konseptual juga tidak hanya dimaknai hak hukum, tetapi hak hukum tersebut dapat dimaknai sebagai hak kebendaan. Adapun hak kebendaan yang dimaksudkan berupa hak kebendaan yang sifatnya tidak berwujud. Oleh karena hak cipta sebagai hak kebendaan yang sifatnya tidak berwujud, hak kebendaan ini secara hukum dimungkinkan untuk dialihkan atau diperalihkan. Dialihkan dan diperalihkannya hak cipta ini, memiliki nilai manfaat yang tinggi bagi kemajuan dan kesejahteraan masyarakat (Riswandi, dan Sujitno, 2016: 81).

Ada beberapa cara peralihan hak cipta, salah satunya yaitu dengan diwakafkan. Hal tersebut secara tegas telah disebutkan dalam Pasal 16 ayat (3) huruf c Undang-Undang Nomor 41 Tahun 2004 jo Pasal 16 ayat (2) Undang-undang Nomor 28 Tahun 2014, yang menyatakan,"hak cipta dapat beralih atau dialihkan, baik seluruh maupun sebagian karena: a. Pewarisan; b. Hibah; c. Wakaf; d. Wasiat; e. Perjanjian tertulis; f. Sebab lain yang dibenarkan sesuai dengan ketentuan peraturan perundang-undangan." Berdasarkan UUHC 2014 bahwa hak cipta yang dialihkan melalui wakaf pada dasarnya hanyalah hak ekonominya atau pemanfaatan ekonominya saja, sementara hak moralnya tidak dapat dialihkan karena merupakan hak yang melekat secara pribadi pada diri pencipta.

\section{c. Wakaf}

Wakaf menurut bahasa berasal dari kata waqf (Bahasa Arab) yang didasarkan dari kata kerjawaqafa-yaqifu-waqfan yang berarti ragu-ragu, berhenti, memperlihatkan, memperhatikan, meletakkan, mengatakan, mengabdi, memahami, mencegah, menahan, dan tetap berdiri. Sementara secara istilah, menurut Mazhab Hanafi wakaf adalah tidak melakukan suatu tindakan atas suatu benda yang berstatus tetap sebagai hak milik, dengan menyedekahkan manfaatnya kepada pihak kebajikan (sosial), baik sekarang maupun akan datang, misalnya wakaf buah kelapa. Mazhab Maliki berpendapat bahwa sesuatu yang diwakafkan itu bisa untuk selamanya atau boleh dalam waktu tertentu, artinya boleh tidak melepaskan harta yang diwakafkan dari kepemilikan wakif namun wakaf tersebut mencegah wakif melakukan tindakan yang dapat melepaskan kepemilikannya atas harta tersebut kepada yang lain dan wakif berkewajiban menyedekahkan manfaatnya serta tidak boleh menarik kembali wakafnya. Perbuatan menjadikan manfaat hartanya untuk digunakan oleh mauqūf bih (penerima wakaf), walaupun yang demikian itu berbentuk upah, atau menjadikan hasilnya untuk dapat digunakan seperti mewakafkan uang. Adapun menurut Mazhab Syafii dan Hambali wakaf adalah tidak melakukan suatu tindakan atas suatu benda yang berstatus sebagai milik Allah Swt dengan menyedekahkan manfaatnya kepada kebajikan (sosial) (Syaikh Al-'Allamah Muhammad, 2012: 289).

Majelis Ulama Indonesia (MUI) memberikan definisi wakaf sebagaimana tercantum pada Fatwa MUI tentang Wakaf Uang, bahwa wakaf adalah menahan harta yang dapat dimanfaatkan tanpa lenyap bendanya, dengan cara tidak 
melakukan tindakan hukum terhadap benda tesebut, disalurkan pada sesuatu yang mubah (tidak haram) atau perbuatan hukum seseorang atau kelompok orang atau badan hukum yang memisahkan sebagian dari benda miliknya guna kepentingan ibadah atau keperluan umum lainnya sesuai dengan ajaran Islam.

Berdasarkan Pasal 1 ayat (1) Undang-Undang Nomor 41 Tahun 2004, wakaf adalah perbuatan hukum wakif untuk memisahkan dan/atau menyerahkan sebagian harta miliknya untuk dimanfaatkan selamanya atau untuk jangka waktu tertentu sesuai dengan kepentingannya guna keperluan ibadah dan/atau kesejahteraan umum menurut syariah. Sementara wakaf berdasarkan PP. Nomor 28 Tahun 1977 adalah perbuatan hukum seseorang atau badan hukum yang memisahkan sebagian dari harta kekayaannya yang berupa tanah milik dan kelembagaannya untuk selama-lamanya untuk kepentingan atau keperluan umat lainnya sesuai ajaran Islam. Selain itu, wakaf berdasarkan Pasal 215 ayat (1) Kompilasi Hukum Islam (KHI) adalah perbuatan hukum seseorang atau kelompok orang atau badan hukum yang memisahkan sebagian dari benda miliknya dan melembagakannya untuk selama-lamanya guna kepentingan ibadah atau keperluan umum lainnya sesuai dengan ajaran Islam.

Pengertian wakaf dalam peraturan perundang-undangan tersebut memiliki implikasi dan ketentuan hukum yang berbeda. Disebutkan dalam PP. Nomor 28 Tahun 1977 bahwa harta wakaf hanya terbatas pada tanah milik dan harta wakaf bersifat abadi. Adapun di dalam Kompilasi Hukum Islam wakif atau orang yang mewakafkan boleh dari sekelompok orang, tidak terbatas pada badan hukum atau perorangan. Selain itu dalam KHI juga disebutkan bahwa harta wakaf bukan hanya berupa tanah milik, melainkan dari benda apapun yang dimiliki sah oleh wakif. Sementara dalam Undang-Undang Nomor 41 Tahun 2004 juga PP. Nomor 42 Tahun 2006 tentang Pelaksanaan Undang-Undang Nomor 41 Tahun 2004, yang merupakan peraturan yang mengatur tentang pelaksanaan wakaf produktif dijelaskan bahwa wakaf juga dapat diberikan jangka waktu tertentu dan bahwa aset wakaf juga dapat berupa benda bergerak maupun tidak bergerak.

Benda tidak bergerak sebagaimana dimaksud Undang-undang Wakaf meliputi:

a. Hak atas tanah sesuai dengan ketentuan perundang-undangan yang berlaku baik yang sudah maupun yang belum terdaftar;

b. Bangunan atau bagian bangunan yang terdiri atas tanah sebagaimana dimaksud pada huruf a;

c. Tanaman dan benda lain yang berkaitan dengan tanah;

d. Hak milik atas satuan rumah susun sesuai dengan ketentuan peraturan perundang-undangan yang berlaku; dan

e. Benda tidak bergerak lain sesuai dengan ketentuan syariah dan peraturan perundang-undangan yang berlaku.

Adapun benda bergerak sebagaimana dimaksud Undang-Undang Wakaf adalah harta benda yang tidak bisa habis karena dikonsumsi, meliputi: uang, logam mulia, Surat Berharga, kendaraan, Hak Kekayaan Intelektual/ HKI, hak sewa, dan 
benda bergerak lain sesuai dengan ketentuan syariah dan peraturan perundangundangan yang berlaku.

Objek wakaf berdasarkan Undang-Undang Nomor 41 Tahun 2004, disebut sebagai harta benda wakaf adalah harta benda yang memiliki daya tahan lama dan/atau manfaat jangka panjang serta mempunyai nilai ekonomi menurut syariah. Undang-undang tersebut menjelaskan bahwa harta benda yang dapat diwakafkan apabila dimiliki dan dikuasai oleh wākif secara sah.

Tujuan wakaf berdasarkan Pasal 5 Undang-Undang Wakaf, yaitu untuk memanafaatkan harta benda sesuai dengan fungsi dan tujuannya mewujudkan potensi dan manfaat ekonomis harta benda wakaf untuk kepentingan ibadah dan kesejateraan umum. Adapun fungsi wakaf yaitu:

a. Fungsi ekonomi; salah satu aspek yang terpenting dari wakaf adalah keadaan sebagai suatu sistem transfer kekayaan yang efektif.

b. Fungsi sosial; jika wakaf diurus dan dilaksanakan dengan baik, berbagai kekurangan akan fasilitas dalam masyarakat akan lebih mudah teratasi.

c. Fungsi ibadah; wakaf merupakan bagian dari ibadah dalam melaksanakan perintah Allah SWT, dan untuk memperkokoh hubungan dengan-Nya.

d. Fungsi akhlaq; yaitu wakaf akan menumbuhkan akhlak yang baik, setiap orang rela mengorbankan apa yang paling dicintainya untuk suatu tujuan yang lebih tinggi daripada kepentingan pribadinya.

\section{Prosedur Peralihan Hak Cipta Yang Dijadikan Sebagai Objek Wakaf}

Berdasarkan hasil penelitian yang dilakukan melalui wawancara dengan para responden, yaitu Kepala P3SI Universitas Muhammadiyah Magelang, Kepala BMT Lesyariah Universitas Muhammadiyah Magelang, Majelis Ulama Indonesia (MUI) Kabupaten Magelang, Badan Wakaf Indonesia (BWI), Kementerian Agama Bidang Wakaf Kabupaten Magelang, nādzir, PPAIW Kecamatan Magelang Selatan, dan Wākif; pada dasarnya wakaf dilaksanakan oleh wākif kepada nādzir di hadapan Pejabat Pembuat Akta Ikrar Wakaf (PPAIW) dengan disaksikan oleh dua orang saksi dan dinyatakan secara lisan dan/atau tertulis yang merupakan kehendak dari wākif dan dituangkan dalam akta ikrar wakaf oleh PPAIW. Akta ikrar wakaf harus memuat nama dan identitas wākif, nādzir, data dan keterangan harta benda wakaf, peruntukan harta benda wakaf, dan jangka waktu wakaf.

Secara rinci prosedur peralihan hak cipta sebagai objek wakaf adalah sebagai berikut: pada dasarnya bahwa prosedur pendaftaran harta benda wakaf berpedoman pada Peraturan Pemerintah Nomor 28 Tahun 1977, Undang-Undang Nomor 41 Tahun 2004 dan Peraturan Pemerintah Nomor 42 Tahun 2006. Para responden berpendapat bahwa prosedur pendaftaran wakaf dengan objek hak cipta sebenarnya hampir sama dengan objek wakaf yang lain, akan tetapi jika yang diwakafkan hak cipta maka ada satu syarat yang harus dipenuhi oleh wākif, yaitu harus disertai bukti pendaftaran (penulis: pencatatan) hak cipta dari Direktorat Jenderal Kekayaan Intelektual (Dirjen KI) Kementerian Hukum dan HAM, sebagai bukti kepemilikan hak atas ciptaan yang akan diwakafkan. Syarat ini merupakan syarat administrasi yang harus dipenuhi dalam pembuatan akta ikrar wakaf (AIW), 
karena dalam AIW harus dicantumkan surat pendaftaran (penulis: pencatatan) hak cipta sebagai objek wakaf.

Hal tersebut menurut penulis berbanding terbalik dengan yang diatur di dalam UUHC, yaitu bahwa tidak ada kewajiban untuk mencatatkan hak cipta, karena hak cipta lahir secara otomatis sejak ciptaan tersebut selesai diwujudkan. Jadi tanpa dicatatkanpun hak cipta tersebut tetap mendapatkan perlindungan (Pasal 64 ayat (2) UUHC 2014).

Mengenai ikrar wakaf dengan objek hak cipta, juga tidak ada perbedaannya dengan objek wakaf benda tetap, bedanya jika yang diwakafkan hak cipta, maka dalam ikranya harus menyebutkan bahwa objek wakafnya adalah hak cipta. Selain itu juga menyebutkan tujuan wakaf dan jangka waktu wakaf (berapa lama hak cipta tersebut diwakafkan). Prosedur peralihan hak cipta sebagai objek wakaf, yaitu sebagai berikut:

a. Seseorang/ calon wākif yang akan mewakafkan hak ciptanya menghadap ke Pejabat Pembuat Akta Ikrar Wakaf (PPAIW) untuk melaksanakan ikrar wakaf, dengan membawa surat-surat: a) Surat pendaftaran (penulis: pencatatan) ciptaan dari Dirjen KI Kementerian Hukum dan HAM; b) Surat keterangan dari Kepada Desa yang disahkan oleh Kepala Kecamatan setempat yang menerangkan kebenaran pemilikan hak cipta dan tidak sedang dalam sengketa; c) Izin dari Direktorat Jenderal Kekayaan Intelektual (Dirjen KI) bahwa hak cipta tersebut akan dialihkan. Selanjutnya PPAIW memeriksa persyaratan tersebut, apakah sudah memenuhi untuk pelepasan hak cipta (untuk diwakafkan), juga saksisaksi, setelah itu kemudian mengesahkan susunan nādzir. Apabila calon wākif tidak dapat datang ke hadapan PPAIW karena suatu sebab, dapat membuat ikrar wakaf secara tertulis dengan persetujuan Kepala Kantor Kementerian Agama Kabupaten/ Kota mengenai hak cipta yang akan diwakafkan di hadapan dua orang saksi, kemudian ikrar wakaf tersebut dibacakan Nãdzir di hadapan PPAIW.

b. Wākif mengucapkan ikrar kepada Nādzir di hadapan PPAIW dengan disaksikan oleh dua orang saksi. Ikrar tersebut harus diucapkan dengan jelas dan tegas, dan kemudian dituangkan dalam bentuk tertulis (akta ikrar wakaf). Bagi wākif yang tidak dapat mengucapkan ikrarnya secara lisan, maka wākif dapat menyatakan kehendaknya itu dengan bahasa isyarat (jika tidak dapat bicara) atau menunjuk seorang kuasa dengan surat kuasa khusus (sesuai prosedur pemberian kuasa khusus, yaitu bunyi ikrarnya secara jelas dan tegas dicantumkan dalam surat kuasa).

c. Setelah wākif selesai melakukan ikrar wakaf, kemudian semua yang terlibat dalam ikrar wakaf menandatangani formulir ikrar wakaf yang bentuk dan isinya telah dibakukan di dalam peraturan Direktoral Jenderal Bimbingan Masyarakat Islam tanggal 18 April 1978 Nomor Kep/D/75/78. Setelah itu kemudian PPAIW membuat akta ikrar wakaf dalam rangkap tiga dan diberi materai. Akta ikrar wakaf tersebut minimal memuat: nama 
dan identitas wākif, nama dan identitas Nādzir, harta benda yang diwakafkan, peruntukan harta benda wakaf dan jangka waktu wakaf. Akta ikrar wakaf tersebut paling lambat satu bulan harus sudah disampaikan kepada pihak-pihak yang bersangkutan. Selanjutnya PPAIW membukukan ke dalam Daftar Akta Ikrar Wakaf.

Prosedur peralihan hak cipta sebagai objek wakaf tersebut jika dicermati sebenarnya telah sesuai dengan Undang-Undang Wakaf, yaitu Pasal 1 angka 3, Pasal 17 dan Pasal 18, hanya bedanya ada syarat khusus yang berupa surat pendaftaran (penulis: pencatatan) hak cipta ke Dirjen KI, Kementerian Hukum dan HAM, sebagai bukti bahwa hak cipta yang akan diwakafkan tersebut adalah miliknya, selain itu bahwa surat pencatatan tersebut merupakan keabsahan dari suatu perbuatan hukum perwakafan dengan objek hak cipta. Setelah hak cipta tersebut diwakafkan, maka seyogyanya juga dicatatkan lagi ke Dirjen KI bahwa hak ciptanya telah dialihkan dengan proses wakaf.

\section{Akibat Hukumnya Terhadap Si Pencipta Jika Hak Cipta Diwakafkan}

Akibat hukum peralihan hak cipta sebagai objek wakaf juga hampir sama dengan wakaf dengan objek yang lain. Hak Cipta berdasarkan ketentuan Pasal 16 ayat (2) UUHC 2014 dapat beralih atau dialihkan baik untuk keseluruhan maupun sebagian. Hak yang dapat beralih atau dialihkan baik seluruhnya maupun sebagian hanyalah hak ekonominya saja, yaitu hanya pemanfaatan secara ekonomi saja, sedangkan untuk hak moralnya tetap melekat pada diri si penciptanya. Jika yang diwakafkan hak ekonominya maka beralihnya hak tersebut hanya sebatas jangka waktu yang disebutkan dalam akta ikrar wakaf. Ketika jangka waktu wakafnya sudah habis maka hak tersebut kembali kepada wākif. Hal ini sesuai dengan UndangUndang Wakaf maupun PP Nomor 42 Tahun 2006 wakaf dapat hanya untuk jangka waktu tententu dan juga dapat berupa benda tidak bergerak maupun benda bergerak, benda bergerak ini termasuk benda bergerak yang tidak berwujud, misalnya HKI (dalam pembahasan ini adalah hak cipta). Adanya perluasan objek wakaf, maka wakaf dengan objek hak cipta ini tergolong dalam wakaf dengan jangka waktu tertentu, karena perlindungan hak cipta memiliki batas waktu sesuai dengan ciptaan yang dihasilkan, yaitu ada yang seumur hidup pencipta ditambah 70 tahun setelah pencipta meninggal dunia; ada yang 50 tahun; 25 tahun terhitung sejak pertama kali diumumkan, bahkan ada yang masa perlindungan hak ekonominya hanya 20 tahun saja sejak pertamakali disiarkan [Pasal 58, Pasal 59, Pasal 60 ayat (3), Pasal 63 UUHC 2014].

Menurut responden Agus Miswanto (ketua P3SI UMMagelang) dan Khamim Setiawan (Penyelenggara Syariah Kementrian Agama Kabupaten Magelang), akibat hukum peralihan hak cipta sebagai objek wakaf adalah sah setelah wākif mengucapkan ikrar wakaf, maka benda wakaf sudah beralih dari wākif kepada penerima wakaf termasuk mauquf 'alaihnya, untuk dimanfaatkan, dan tidak boleh dijual dialihkan/ kepada pihak lain. Di sisi lain wākif juga sudah tidak berhak lagi untuk memanfaatkan hak cipta tersebut, meskipun hak moralnya masih melekat pada wākif. 


\section{Keabsahan Wakaf Hak Cipta Yang Dibatasai Waktu Kepemilikan Haknya}

Selanjutnya berkaitan dengan keabsahan batasan waktu hak cipta sebagai objek wakaf ini juga berkaitan dengan akibat hukum peralihannya. Berdasarkan Pasal 215 ayat (1) Kompilasi Hukum Islam (KHI) disebutkan bahwa wakaf adalah perbuatan hukum seseorang atau sekelompok orang atau badan hukum yang memisahkan sebagian dari harta miliknya dan melembagakannya untuk selamalamanya guna kepentingan ibadat atau kepentingan umum lainnya sesuai dengan ajaran Islam. Ketentuan tersebut dapat dipahami bahwa KHI tidak mengenal wakaf yang sifatnya sementara/ untuk jangka waktu tertentu saja. Sementara itu dalam Pasal 1 angka 1 UU Nomor 41 Tahun 2004, menyatakan bahwa wakaf adalah perbuatan hukum wākif untuk memisahkan dan/ atau menyerahkan sebagian harta benda miliknya untuk dimanfaatkan selamanya atau untuk jangka waktu tertentu sesuai dengan kepentingannya guna keperluan ibadah dan/ atau kesejahteraan umum menurut syariah, misalnya wakaf kekayaan intelektual (KI).

Wakaf dengan objek hak cipta dalam penelitian ini termasuk wakaf yang sifatnya sementara, karena perlindungan hukum terhadap hak cipta ada batasan waktunya sesuai dengan hasil karya ciptaannya. Seperti telah disebutkan di atas bahwa batas waktu perlindungan hukum hak ekonomi untuk hasil karya cipta berbeda-beda. Misalnya batas waktu perlindungan hukum untuk ciptaan turunan (derivatif) yaitu 25 (dua puluh lima) tahun sejak pertama kali dilakukan Pengumuman.

Menurut Mazhab Imam Malik, bahwa sesuatu yang diwakafkan itu bisa untuk selamanya atau boleh dalam waktu tertentu artinya boleh tidak melepaskan harta yang diwakafkan dari kepemilikan wākif namun wakaf tersebut mencegah wākif melakukan tindakan yang dapat melepaskan kepemilikannya atas harta tersebut kepada yang lain dan wākif berkewajiban menyedekahkan manfaatnya serta tidak boleh menarik kembali wakafnya. Pemanfaatan hartanya untuk digunakan oleh mauquf bih (penerima wakaf), walaupun yang dimilikinya itu berbentuk upah, atau menjadikan hasilnya untuk dapat digunakan seperti mewakafkan uang. Pendapat Imam Malik tersebut dapat dipahami bahwa, wakaf sementara atau berjangka waktu tertentu tersebut diperbolehkan, dalam hal ini adalah wakaf dengan objek hak cipta, atau dengan kata lain batas waktu wakaf boleh dibatasi. Namun, harus sesuai dengan kemanfaatan atau kepentingannya guna keperluan ibadah dan/ atau kesejahteraan umat Islam menurut syariat Islam. Hal ini senada yang dikatakan para responden antara lain yang disampaikan oleh Nasyitotul Janah (direktur BMT Lesyariah UMMagekang), Agus Miswanto, dan Khamim Setiawan, bahwa wakaf dengan dibatasi jangka waktu itu diperbolehkan, yang terpenting adalah azas kemanfaatannya dan kegunaannya. Sementara ada renponden yang menyatakan mewakafkan hak cipta adalah tidak sah, alasannya bahwa wakaf itu untuk selamanya dan tidak dapat ditarik kembali. Jadi ada perdebatan tentang wakaf yang ada batasan waktunya. Namun jika dipahami pendapat dari para alim ulama bahwa wakaf hak cipta itu diperbolehkan. 
Di samping itu, hak cipta sebagai harta benda wakaf juga diatur di dalam Undang-Undang No. 41 Tahun 2004 yang menyatakan kekayaan intelektual telah ditetapkan sebagai harta benda wakaf, yaitu termasuk benda bergerak. Oleh karena hak cipta diakui sebagai harta benda wakaf, maka proses perwakafannya dapat diterapkan terhadap hak cipta. Hal ini dipertegas lagi dengan ketentuan Pasal 16 ayat (2) UUHC 2014, yaitu bahwa hak cipta dapat dialihkan dan beralih melalui mekanisme wakaf. Perlihan tersebut harus dilakukan secara jelas dan tertulis baik dengan atau tanpa akta notaris.

Uraian tersebut di atas dapat dimaknai bahwa peralihan hak cipta sebagai objek wakaf secara filosofis telah didukung oleh agama, baik dari mazhab, dan para responden ulama, hal ini bahwa wakaf hak cipta merupakan wakaf yang mempunyai nilai kemanfaatan. Hal tersebut juga didukung oleh Fatwa MUI Nomor 1 tahun 2003 tentang hak cipta, yaitu bahwa hak cipta merupakan salah satu hak kekayaan yang perlu mendapat perlindungan hukum, sepanjang hak cipta tersebut tidak bertentangan dengan hukum Islam. Secara sosiologis, wakaf hak cipta telah berkembang dan dibutuhkan di masyarakat, hal ini terlihat dari pendapat para responden yang membolehkan wakaf yang dibatasi oleh jangka waktu tertentu, sedangkan secara yuridis diatur dalam peraturan perundang-undangan. Secara yuridis karena telah dipertegas dalam Undang-undang Nomor 41 Tahun 2004 dan Undang-undang Nomor 28 Tahun 2014 yang telah mengatur tentang peralihan hak cipta sebagai objek wakaf, dimana ada batasan jangka waktu wakaf yang diikrarkan dalam akta wakaf oleh wākif kepada penerima wakaf.

Selain itu salah satu keabsahan suatu tindakan perwakafan yang dinilai dari unsur wakaf yang diatur dalam Undang-undang Nomor 41 Tahun 2004, yaitu peruntukan harta benda wakaf adalah kegunaan dari harta benda wakaf yang diwakafkan oleh wākif. Untuk memenuhi tujuan dan fungsi wakaf, maka wakaf hanya bisa diperuntukan sebagai sarana dan kegiatan ibadah, sarana dan kegiatan pendidikan dan kesehatan, bantuan kepada fakir miskin, anak terlantar, yatim piatu, bea siswa, serta kemajuan dan peningkatan ekonomi umat atau hal-hal yang berhubungan dengan kesejahteraan umum lainnya yang tidak bertentangan dengan syariah dan peraturan perundang-undangan.

Sebagai contoh yang perlu dipahami agar tidak menimbulkan kesalahpahaman dalam memaknai wakaf dengan objek hak cipta. Ada seorang wākif (http://digilib.uinsby.ac.id) yang mewakafkan 100 eksemplar buku, tetapi tanpa pernyataan wakaf secara tertulis dan juga tidak mengikrarkan/ mengucapkan ikrar wakaf. Hal tersebut dapat dipahami bahwa wākif tersebut hanya mengejar pahala dari Allah SWT semata, tidak untuk mendapatkan pengakuan dari masyarakat bahwa ia telah mewakafkan suatu karya cipta yang dapat bermanfaat bagi para pembacanya dan berharap bahwa bukunya tersebut berguna dan bermanfaat bagi para pembaca baik dalam bidang akademis maupun bidang lainnya. Wakaf yang demikian ini bukan merupakan wakaf hak cipta, melainkan merupakan wakaf benda bererak yang berwujud buku, yaitu suatu ciptaan yang diekspresikan dalam bentuk nyata (buku), sehingga buku tersebut dapat diwakafkan untuk selamanya. 
Adapun yang dimaksud dengan wakaf hak cipta atas buku, adalah jika seorang penulis/ pengarang buku (pencipta) yang mempunyai hak cipta atas bukunya tersebut kemudian mewakafkan hak ciptanya (hak ekonomi) sebagai penulis buku. Buku hasil karyanya tersebut telah diwakafkan oleh penulis (pencipta) untuk dimanfaatkan hak ekonominya, yaitu baik untuk penerbitan pendistribusian maupun penjualannya. Royalty yang diterima oleh mauquf bih (penerima wakaf), merupakan sedekah/ royalty dari hak penulis sebagai wākif . Jadi hak mauqūf bih berdasarkan hasil dari royalty penerbitan/ penjualan buku yang telah diwakafkan tersebut.

\section{KESIMPULAN DAN SARAN}

\section{Kesimpulan}

Prosedur peralihan hak cipta sebagai objek wakaf, secara teknis tidak jauh berbeda dengan prosedur wakaf dengan objek wakaf yang lain. Bedanya terletak pada adanya keharusan melampirkan surat pendaftaran ciptaan dari Direktorat Jenderal Kekayaan Intelektual (Dirjen KI). Fungsi dari surat pendaftaran ciptaan tersebut di samping sebagai keabsahan kepemilikan hak atas ciptaan yang akan diwakafkan, juga merupakan syarat administrasi dalam pembuatan akta ikrar wakaf.

Akibat hukum peralihan hak cipta sebagai objek wakaf yaitu berdasarkan ketentuan Pasal 16 ayat (1) UUHC 2014 bahwa hak cipta dianggap sebagai benda yang bergerak, sehingga dapat beralih atau dialihkan baik secara keseluruhan maupun sebagian, sehingga akibat hukumnya hampir sama dengan wakaf yang lain, yang membedakan hanyalah batasan perlindungan hukumnya. Wakaf dengan objek tanah biasanya untuk selamanya, tetapi untuk wakaf dengan objek hak cipta dapat seumur hidup ditambah 70 (tujuh puluh) tahun, atau sesuai dengan ikrar wakaf. Adapun hak yang dapat beralih atau dialihkan baik seluruhnya maupun sebagian hanyalah hak ekonominya saja, sedangkan hak moralnya tetap melekat pada diri penciptanya. Bagi wākif, setelah mewakafkan hak ciptanya maka hak ekonominya sudah beralih kepada penerima wakaf, tetapi hak moralnya tetap melekat pada diri pencipta (wākif).

Kompilasi Hukum Islam (KHI) tidak mengenal batasan waktu wakaf/ wakaf yang sifatnya sementara, akan tetapi berdasarkan Undang-UndangNomor 41 Tahun 2004 memperbolehkan wakaf sementara asalkan sesuai dengan kepentingannya dan manfaat yang diperolehnya. Misalnya wakaf dengan objek hak cipta, termasuk ke dalam wakaf sementara karena ada batasan waktu perlindungan hukumnya.

Menurut Mazhab Imam Malik, bahwa sesuatu yang diwakafkan itu bisa untuk selamanya atau boleh dalam waktu tertentu. Di samping itu, hak cipta sebagai harta benda wakaf juga diakui di dalam Undang-undang Nomor 41 Tahun 2004 yang menyatakan bahwa HKI telah ditetapkan sebagai harta benda wakaf. Hal ini juga dipertegas dalam Pasal 16 ayat (2) Undang-Undang No. 28 Tahun 2014, bahwa hak cipta dapat dialihkan dan beralih melalui mekanisme wakaf. 


\section{Saran}

Badan Wakaf Indonesia (BWI), selain sebagai Nādzir (pengelola wakaf), agar lebih memaksimalkan peranya, yaitu tidak hanya sebagai pengelola harta benda wakaf saja, namun juga agar dapat mengembangkan harta wakaf secara produktif, sesuai dengan pemanfaatannya, selain juga mensosialisasikan wakaf yang terkait dengan HKI. Nādzir juga harus melakukan pengadministrasian, pengawasan dan melindungi harta benda wakaf. Hal ini sesuai dengan PP Nomor 42 Tahun 2006, yang mengatur bahwa harta benda wakaf harus didaftarkan atas nama Nādzir untuk dikelola sesuai peruntukan dan pemanfaatannya. Oleh karena itu berkaitan dengan hak cipta sebagai objek wakaf, maka Nādzir wajib melakukan pendaftaran ulang terkait hak cipta yang diwakafkan selaku pengelola/ pengurus objek wakaf, yang namanya tercantum dalam pendaftaran baik dalam akta ikrar wakaf maupun instansi terkait (Dirjen KI).

Pejabat Pembuat Akta Ikrar Wakaf (PPAIW), hendaknya memilah/ mengklasifikasikan Akta Ikrar Wakaf, yaitu antara wakaf umum dengan wakaf HKI (misalnya wakaf hak cipta). Hal ini karena wakaf dengan objek hak cipta ada kekhususannya, yaitu mengenai isi ikrar wakafnya, karena dilihat dari sisi objeknya merupakan wakaf benda bergerak yang tidak berwujud maka harus dibedakan.

Pemerintah hendaknya melakukan sosialisasi kepada masyarakat bahwa saat ini objek wakaf tidak hanya berupa benda tidak bergerak saja, tetapi dapat pula berupa benda bergerak, bahkan benda bergerak yang tidak berwujud, yaitu HKI misalnya hak cipta, karena banyak masyarakat yang belum mengetahui bahwa hak cipta dapat dijadikan sebagai objek wakaf. Sementara yang diketahui oleh masyarakat umum yang diwakafkan bukan hak ciptanya, tetapi wujud dari hak ciptanya, misalnya mewakafkan buku yang jumlahnya sekian eksemplar.

Banyaknya kendala yang belum terwadahi dalam peraturan perundangundangan terkait wakaf dengan objek HKI, khususnya peralihan hak cipta sebagai objek wakaf, yaitu misalnya jika terjadi sengketa atau pelanggaran terhadap hak cipta yang diwakafkan tersebut. Siapakah yang berhak/ berkewajiban untuk mempertahankannya? Apakah pencipta (wākif) atau penerima wakaf sebagai pihak yang menerima hak ekonominya, sementara hak moralnya masih melekat pada si pencipta. Belum lagi jika salah satu pihak (wākif/ penerima wakaf) meninggal. Apakah dalam hal ini juga berlaku hak kualitatif ataupun kewajiban kualitafif? Oleh karena itu hendaknya dibentuk suatu pranata dalam bentuk peraturan perundangundangan untuk memaksimalkan dan mengimplementasikan wakaf dengan objek HKI sebagai sarana peralihan hak hukum.

\section{DAFTAR PUSTAKA}

\section{A. BUKU}

Muhammad, Addulkadir (2001). Kajian Hukum Ekonomi Hak Kekayaan Intelektual. Bandung: Citra Aditya Bakti

Purba, Afrillyana (2009). Perlindungan Hukum Seni Batik Tradisional. Bandung: PT. Alumni. 
Riswandi, Budi Agus dan Sujitno (2016). Wakaf Hak Kekayaan Intelektual: Hak Cipta sebagai objek Wakaf. Yogyakarta: Pusat HKI FH UII Press.

Riswandi, Budi Agus, Febriyanti, dan Ratna, Wiwin Dwi (2016). Wakaf Hak Kekayaan Intelektual: Kelembagaan Hak Kekayaan Intelektual dan Pengembangan Ekonomi Kreatif Bagi Creative City. Yogyakarta: Pusat HKI FH UII Press.

Lita, Helza Nova (2016). Wakaf Hak Kekayaan Intelektual: Peralihan Hak Kekayaan Intelektual (HKI) melalui Wakaf. Yogyakarta: Pusat HKI FH UII Press.

Sutedi, Adrian (2009). Hak Kekayaan Intelektual. Jakarta: Sinar Grafika.

Soelistyo,Henry (2011). Hak Cipta Tanpa Hak Moral. Jakarta : PT. Raja Grafindo Persada.

Djumhana, Muhammad (1995). Hukum dalam Perkembangan Bioteknologi. Bandung: PT. Citra Aditya Bakti.

Soekanto,Soerjono (2005). Pengantar Penelitian Hukum. Jakarta: Universitas Indonesia.

Margono, Suyud (2010). Hukum Hak Cipta Indonesia. Bogor: Ghalia Indonesia. (2003). Hukum dan Perlindungan Hak Cipta. Jakarta: CV. Novindo Pustaka Mandiri.

bin Abdurahman Ad-Dimasyqi, Syaikh Al-'Allamah Muhammad (2012). Fikih Empat Mazhab. Bandung: Masyim.

\section{B. Peraturan PerUndang-Undangan}

Undang-Undang Nomor 41 Tahun 2004 tentang Wakaf

Undang-Undang Nomor 28 Tahun 2014 tentang Hak Cipta

Peraturan Pemerintah Nomor 42 Tahun 2006 tentang Pelaksanaan Undang-Undang Nomor 41 Tahun 2004 tentang Wakaf

Inpres Nomor 1 Tahun 1991 tentang Kompilasi Hukum Islam(KHI) 